\title{
Evaluation of Some Fungicides and Bio-Agents against Sclerotium rolfsii and Foot and Root Rot Disease of Eggplant (Solanum melongena L.)
}

\author{
Mohammad Nuray Alam Siddique ${ }^{1 *}$, Abu Noman Faruq Ahmmed ${ }^{2}$, \\ Md. Golam Hasan Mazumder ${ }^{1}$, M. O. Khaiyam ${ }^{3}$ and Md. Rafiqul Islam ${ }^{2}$ \\ ${ }^{I}$ Department of Agricultural Extension, GoB, Bangladesh; ${ }^{2}$ Department of Plant Pathology, Sher-e- \\ Bangla Agricultural University, Dhaka, Bangladesh; ${ }^{3}$ Bangladesh Sugarcrop Research Institute, \\ Ishurdi, Pabna, Bangladesh
}

*Corresponding author and Email: nurayalam88@gmail.com

Received: 20 February 2016

Accepted: 12 June 2016

\begin{abstract}
Two experiments were conducted in a complete randomized design (CRD) with three replications to evaluate the efficacy of some fungicides and bio-agents against foot and root rot of eggplant. Ten treatments including five fungicides, two plant extracts, one poultry manure and an antagonist were evaluated against the disease and its causal agent. Fungicides and plant extracts were sprayed at the base of each plant and adjacent soil at 40, 50 and 60 days after transplanting (DAT). Poultry manure and bio-agent were applied to the soil before transplanting. The highest reduction of mycelium growth $(74.44 \%)$ and sclerotia production $(77.13 \%)$ were recorded in Bavistin $50 \mathrm{WP}$ by poison food technique. Topgan $50 \mathrm{WP}$ and Ridomil Gold also had similar effects. The lowest incidence (7.10 \%) of foot rot was observed in Bavistin $50 \mathrm{WP}$ at 120 DAT that was similar with Topgan $50 \mathrm{WP}$ and Ridomil Gold. The lowest disease severity (stem lesion area) was also found in each of Bavistin 50 WP (0.71 $\mathrm{cm}$ ) and Topgan 50 WP which resulted in higher yield (18.07 ton/ha). Application of bio-agent (Trichoderma harzianum) also showed promising effect against foot and root rot disease. Bavistin 50 WP is therefore recommended for controlling the foot and root rot of eggplant.
\end{abstract}

Keywords: Sclerotium rolfsii, fungicides, bio-agents, eggplant

\section{Introduction}

Eggplant (Solanum melongena L.), also known as brinjal is an important vegetable crop in Bangladesh (BBS, 2011). It is being cultivated in almost all districts and consumed as a cooked vegetable in various ways. It is a small short lived perennial herb belonging to the family solanaceae of dicot angiosperm. More than ten diseases of eggplant have been reported in Bangladesh (Islam, 2005). Dasgupta et al. (2000) reported the highest intensity of foot and root rot and leaf rot of eggplant recorded in Midnapore and Nadia districts of India. Among them, foot and root rot may cause up to 30-50 \% loss in fruit yield of eggplant (BARI, 2000).

The fungus Sclerotium rolfsii is a facultative saprophyte and can maintain continuity of its generation under adverse situation by the formation of sclerotia (Ahmed, 1980). As the fungus Sclerotium rolfsii is soil borne and omnipathogenic, it is very difficult to control even by the use of chemical fungicides. Some fungicides such as Bavistin $50 \mathrm{WP}$, Topgan 50 WP, Dithane M-45 and Bordeaux mixture have 
been reported to be effective to control foot and root rot disease of eggplant caused by Sclerotium rolfsii (Dasgupta and Maiti, 2008; Johnson and Reddy, 2008; Tiwari and Ashok, 2004 and Patil et al., 1986). Biological control could be successful alternative to chemicals. Many species of fungi and bacteria are reported to be effective as bio-control agents against soil borne plant pathogens (Mukhopadhyay, 1994 and Bari, 2000). Trichoderma spp. are antagonists to many plant pathogenic fungi. They are potential biocontrol agent againsts several soil borne plant pathogenic fungi (Faruq et al., 2014; Saralamrna and Vithal, 2003; Pranab Datta and Das, 2002 and Biswas and Sen, 2000). Anti-fungal activities of garlic, neem, alamanda, have been reported by many researchers (Faruq et al., 2014; Islam, 2005; Rahman et al., 1999; Arun et al., 1995; Mohanty et al., 2000 and Gurjar et al., 2003).

The present study was therefore undertaken to evaluate some fungicides, plant extracts, organic manure and bio-agent against the pathogen to find out the most effective management option for foot and root rot of eggplant.

\section{Materials and Methods}

The experiment was conducted in the laboratory and net House of the Department of Plant Pathology, Sher-e-Bangla Agricultural University, Dhaka, during November 2013 to May 2014. The experiment was carried out in a completely randomized design (CRD) with three replications. Ten treatments including five fungicides viz. Bavistin $50 \mathrm{WP}$ (Carbendazim) @ $0.2 \%$, Topgan 50 WP (Copper-oxychloride) @ $0.2 \%$, Ridomil gold MZ 68 WG (Metalaxyl) @ $0.4 \%$, Bordeaux mixture (Cu fungicide) @ 1:1:2 (w/v), and Dithen M-45 (Mancozeb) @ 0.2 $\%$; two plant extracts viz. Neem (Azadirachta indica)@1:2 (w/v) and Allamanda (Allamanda cathertica) leaf extract @ 1:2 (w/v); one poultry manure@ $@ 25$ g/plant and one bio-agent Trichoderma harzainum @ 1.35 x $10^{9}$ spores/plant were tested against foot and root rot of eggplant (variety "Singnath").
Poison food technique was done for in vitro evaluation of selected fungicides, plant extracts and bio-agent against $S$. rolfsii. PDA media and distilled water were sterilized in an autoclave at $121{ }^{\circ} \mathrm{C}$ under 15 PSI for 30 minutes. S. rolfsii was isolated from the infected plants following tissue planting method. Pure culture of the pathogen was prepared following hyphal tip methods and subsequently multiplied on PDA in test tubes and petri dishes (Mian, 1995). Inhibition of radial growth was computed by meaning colony diameter on control plates and treated plates. Moreover, a pot experiment was done to evaluate the selected treatments against foot and root rot disease in net house. Healthy seedlings were transplanted in the earthen pot. Manures and fertilizers were applied properly. $S$. rolfsii were inoculated to the soil in the base of each plant at two months after transplanting.

Data was taken randomly from selected five plants for each plot. Percent growth inhibition, number of sclerotia production, percent disease incidence, stem lesion area $(\mathrm{cm})$ and yield $(\mathrm{t} / \mathrm{ha})$ were recorded at 120 DAT. Data were analyzed statistically and the means were separated by least significant difference (LSD) following MSTAT-C software.

\section{Results and Discussion}

Efficacy of different treatments on radial growth of mycelia and production of sclerotia of Sclerotium rolfsii is shown in Table 1 and Figure 1. The lowest growth of mycelia (1.03, 1.73, 2.06 and $2.30 \mathrm{~cm}$ ) was recorded in case of Bavistin 50 WP, where inhibition was $74.44 \%$. Mycelial growth was the highest in case of control, there was no inhibition of mycelia growth. The lowest number of sclerotia (124.7) was recorded in case of Bavistin 50 WP and Topgan 50 WP (130.7). The highest number of sclerotia (545.3) was recorded in control at 30 days after inoculation. The highest reduction in sclerotia production $(77.13 \%)$ was recorded in case of Bavistin 50 WP and Topgan 50 WP (76.03\%). 
Table 1. Effect of selected fungicides, plant extracts and bio-agent on mycelial growth and sclerotia production of Sclerotium rolfsii

\begin{tabular}{|c|c|c|c|c|c|c|c|}
\hline \multirow[t]{2}{*}{ Treatment } & \multicolumn{4}{|c|}{ Radial growth $(\mathrm{cm})$} & \multirow{2}{*}{$\begin{array}{c}\text { Growth } \\
\text { inhibition } \\
(\%) \\
\text { at } 4 \text { DAI }\end{array}$} & \multirow{2}{*}{$\begin{array}{l}\text { Sclerotia } \\
\text { production } \\
\text { (no) at } \\
30 \text { DAI }\end{array}$} & \multirow{2}{*}{$\begin{array}{c}\text { Sclerotia } \\
\text { reduction } \\
(\%) \text { at } 30 \\
\text { DAI }\end{array}$} \\
\hline & $1 \mathrm{DAI}$ & $2 \mathrm{DAI}$ & $3 \mathrm{DAI}$ & $4 \mathrm{DAI}$ & & & \\
\hline $\mathrm{T}_{1}=$ Control & $2.00 \mathrm{a}$ & $4.20 \mathrm{a}$ & $7.33 \mathrm{a}$ & $9.00 \mathrm{a}$ & - & 545.3 & - \\
\hline $\mathrm{T}_{2}=$ Bavistin $50 \mathrm{WP}$ & $1.03 \mathrm{~d}$ & $1.73 \mathrm{e}$ & $2.06 \mathrm{~g}$ & $2.30 \mathrm{~h}$ & 74.44 & 124.7 & 77.13 \\
\hline $\mathrm{T}_{3}=$ Topgan $50 \mathrm{WP}$ & $1.30 \mathrm{c}$ & $1.80 \mathrm{e}$ & $2.23 \mathrm{~g}$ & $2.80 \mathrm{~g}$ & 68.88 & $130.7 \mathrm{~h}$ & 76.03 \\
\hline $\mathrm{T}_{4}=$ Ridomil Gold & $1.40 \mathrm{bc}$ & $1.93 \mathrm{e}$ & $2.63 \mathrm{f}$ & $3.23 \mathrm{f}$ & 64.07 & 222.7 & 59.16 \\
\hline $\mathrm{T}_{5}=$ Bordeaux mixture & $1.50 \mathrm{bc}$ & $2.66 \mathrm{~d}$ & $3.63 \mathrm{~d}$ & $4.30 \mathrm{~d}$ & 52.22 & 295.0 & 45.90 \\
\hline $\mathrm{T}_{6}=$ Dithane $\mathrm{M}-45$ & $1.60 \mathrm{~b}$ & $2.90 \mathrm{c}$ & $3.66 \mathrm{~d}$ & $4.16 \mathrm{~d}$ & 53.70 & 272.0 & 50.11 \\
\hline $\mathrm{T}_{7}=$ Neem leaf extract & $1.50 \mathrm{bc}$ & $3.10 \mathrm{c}$ & $5.46 \mathrm{c}$ & $6.73 \mathrm{c}$ & 25.18 & 354.0 & 35.08 \\
\hline $\mathrm{T}_{8}=$ Alamanda leaf extract & $1.53 \mathrm{bc}$ & $3.60 \mathrm{~b}$ & $5.86 \mathrm{~b}$ & $7.90 \mathrm{~b}$ & 12.22 & $386.0 \mathrm{~b}$ & 29.21 \\
\hline $\mathrm{T}_{9}=T$. harzianum & $1.33 \mathrm{c}$ & $2.46 \mathrm{~d}$ & $2.96 \mathrm{e}$ & $3.46 \mathrm{e}$ & 61.47 & $314.0 \quad \mathrm{~d}$ & 42.41 \\
\hline
\end{tabular}

Means followed by the same letters in a column did not differ at 5\% level of significance by LSD. DAI $=$ Days after inoculation.
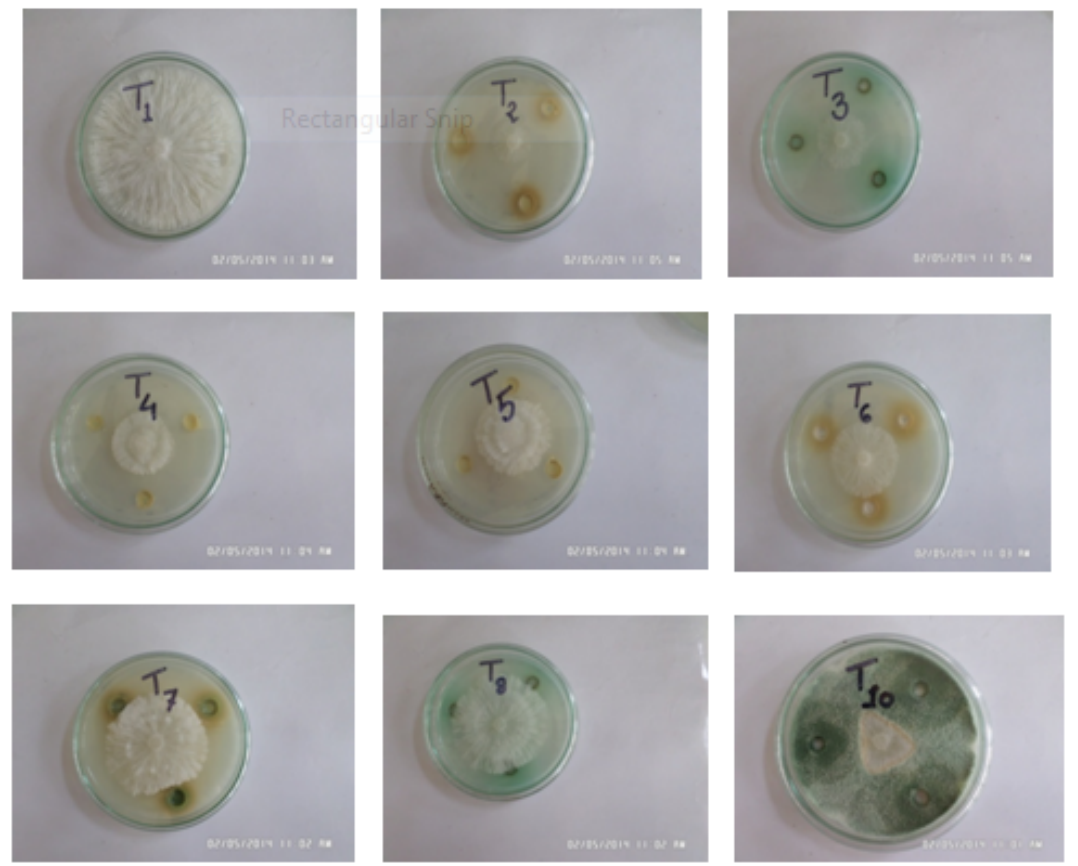

Figure 1. Bioassay of different treatments against Sclerotium rolfsii 
Table 2. Effect of different treatments on disease incidence and disease severity (stem lesion area) at 120 days after transplanting

\begin{tabular}{lccc}
\hline Treatment & \% Disease incidence & Incidence reduction $(\%)$ & Stem lesion area $(\mathrm{cm})$ \\
\hline Control & $64.90 \mathrm{a}$ & - & $2.23 \mathrm{a}$ \\
Bavistin 50 WP & $7.10 \mathrm{e}$ & 89.06 & $0.71 \mathrm{~d}$ \\
Topgan 50 WP & $19.63 \mathrm{de}$ & 69.75 & $0.99 \mathrm{~cd}$ \\
Ridomil Gold & $25.90 \mathrm{cde}$ & 60.09 & $1.16 \mathrm{~cd}$ \\
Bordeaux mixture & $25.90 \mathrm{cde}$ & 60.09 & $1.19 \mathrm{bcd}$ \\
Dithane M-45 & $41.53 \mathrm{abcd}$ & 36.00 & $1.60 \mathrm{bcd}$ \\
Neem leaf extract & $38.43 \mathrm{bcd}$ & 40.78 & $1.59 \mathrm{bcd}$ \\
Alamanda leaf extract & $47.80 \mathrm{abc}$ & 26.34 & $1.83 \mathrm{ab}$ \\
Poultry manure & $62.53 \mathrm{ab}$ & 3.65 & $1.87 \mathrm{ab}$ \\
T. harzianum & $31.93 \mathrm{~cd}$ & 50.80 & $1.40 \mathrm{abc}$ \\
\hline
\end{tabular}

Means followed by the same letters in a column did not differ at 5\% level of significance by LSD.

Table 3. Effect of different treatments on yield of eggplant at 120 DAT

\begin{tabular}{lcc}
\hline Treatment & Yield (ton/ha) & Yield Increase over control (\%) \\
\hline Control & $4.867 \mathrm{~h}$ & - \\
Bavistin 50 WP & $18.07 \mathrm{a}$ & 271.27 \\
Topgan 50 WP & $15.79 \mathrm{~b}$ & 224.42 \\
Ridomil Gold MZ 68WG & $13.41 \mathrm{c}$ & 175.52 \\
Bordeaux mixture & $12.40 \mathrm{~d}$ & 154.77 \\
Dithane M-45 & $10.95 \mathrm{e}$ & 124.98 \\
Neem leaf extract & $10.66 \mathrm{e}$ & 119.02 \\
Alamanda leaf extract & $9.420 \mathrm{f}$ & 93.54 \\
Poultry manure & $7.660 \mathrm{~g}$ & 57.38 \\
Trichoderma harzianum & $11.58 \mathrm{de}$ & 137.92 \\
\hline
\end{tabular}

Means followed by the same letters in a column did not differ at 5\% level of significance by LSD.

Data on the effect of fungicides and bio-agents on the incidence and severity of foot and root rot of eggplant are presented in Table 2. Bavistin 50 WP $(7.10 \%)$, Topgan 50 WP $(19.6 \%)$ and Ridomil Gold MZ 68WG (25.9\%) gave the lowest incidence. The highest disease incidence was recorded in control treatment $(64.9 \%)$ at 120 DAT. The reduction in incidence was the highest in Bavistin 50 WP (89.06 \%), Topgan 50 WP (69.75 \%) and Ridomil Gold (60.09 \%) treated pots. The lowest lesion area was observed in case of Bavistin $50 \mathrm{WP}(0.71 \mathrm{~cm})$ and Topgan 50 WP $(0.99 \mathrm{~cm})$. Neem leaf extract $(1.59 \mathrm{~cm})$ and Trichoderma harzianum $(1.40 \mathrm{~cm})$ also showed better performance as compared to control. The highest lesion area $(2.23 \mathrm{~cm})$ was recored in control.

Effect of different treatments on yield of eggplant is presented in Table 3. The highest yield (18.07 ton/ha) was recorded in Bavistin 50 WP. Topgan produced 15.79 ton/ha and Ridomil gold MZ 68WG yielded 13.41 ton/ha. The yield was 11.58 ton/ha in case of Trichoderma harzianum. The lowest yield (4.86 ton/ha) was recorded in control plot. The highest increase of yield over control $(271.27 \%)$ was recorded in Bavistin $50 \mathrm{WP}$ followed by Topgan $50 \mathrm{WP}$ (224.42 \%) and Ridomil Gold (175.52\%). 


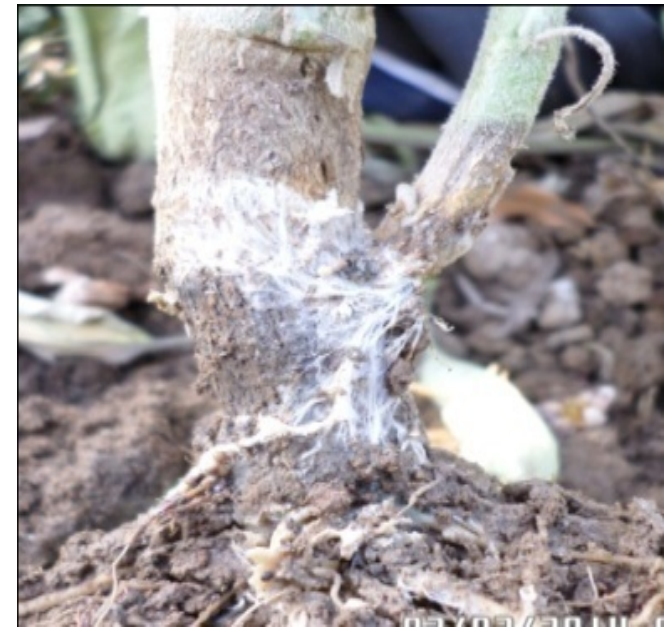

Figure 2. Infected eggplant showing mycelium of Sclerotium rolfsii

From the results of the study it is revealed that Bavistin 50 WP was the best in reducing the incidence of foot and root rot disease and increasing the yield of eggplant. Similar findings were reported on foot and root rot of other crops (Sheoraj et al., 2005; Vanitha and Suresh, 2002; Mishra and Bais, 1987; Dutta, 1975). Neem leaf extract was promising against the Sclerotium rolfsii causing foot and root rot of eggplant (Seshakiran, 2002; Dayaram and Tewari, 1994). Trichoderma harzianum was also effective in controlling Sclerotium rolfsii, the causal agent of foot and root rot of eggplant (Islam, 2005).

\section{Conclusions}

Bavistin 50 WP showed the best effects among the treatments in reducing the foot and root rot disease and increasing the yield of eggplant. So, Bavistin 50 WP may be suggested to use by the farmer for controlling foot and root rot disease of eggplant.

\section{References}

Ahmed, F. 1980. Control of foot and root rot disease of wheat. MS Thesis. Department

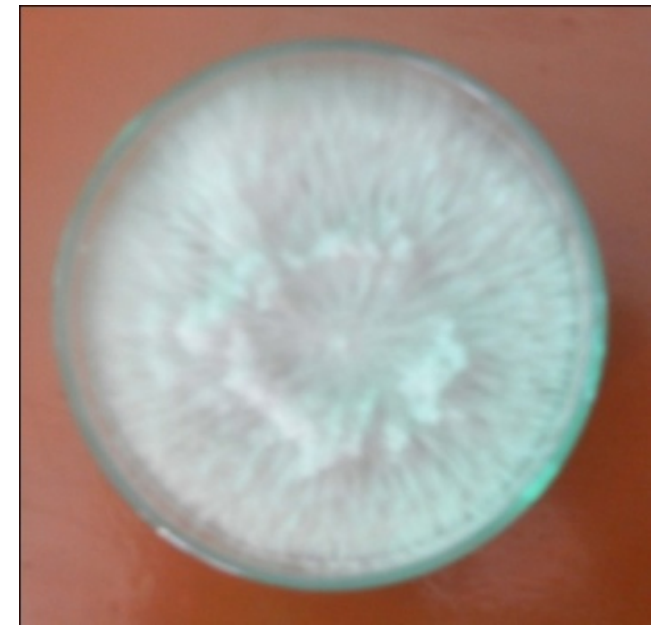

Figure 3. Pure culture of Sclerotium rolfsii

of Plant Pathology, Bangladesh Agricultural University, Mymensingh.

Arun, A. C., Tekha and Chitra, A. 1995. Effects of garlic extracts on two fungi. Indian Journal of Mycological Plant Pathology, 259: 316-318.

Bari M. A. 2000. Effect of fungal antagonistic to suppress foot and root rot of barley. Bangladesh Journal of Plant Pathology, 16: 17-21.

BBS. 2011. Statistical Year Book of Bangladesh. Bangladesh Bureau of Statistics. Statistics Division, Ministry of Planning, Government of the Peoples Republic of Bangladesh, Dhaka.

Biswas, K. K. and Sen, C. 2000. Management of stem rot of groundnut caused by Sclerotium rolfsii through Trichoderma harzianum. Indian Phytopathology, 53(3): 290-295.

Dasgupta, B. and Maiti, 2008. Assessment of Phytophthora root rot of betel vine and its management using chemicals. Indian Journal of Mycological Plant Pathology, 29:91-95. 
Dasgupta, B. 2000. Diseases of plantation crops spices, eggplant and betel vine.133-137 pp.

Dayaram and Tewari, 1994. Collar rot of chickpea caused by Sclerotium rolfsii. Indian Phytopathology, 52(3): 310.

Faruq, A. N., Rahman, M. A., Aminuzzaman, F. M., Mamun-ur-Rashid, M. and Hoque, S. 2014. In vitro evaluation of plant extracts against seed borne bacteria and fungi of hybrid rice. Applied Science Reports, 4(2):61-68.

Faruq, A. N., Islam, M. T. Bhuiyan, M. Z. R.., Mamun-ur-Rashid, M., Amin, M. R. and Hoque, S. 2014. Efficacy of soil application with Trichoderma harzianum $\mathrm{T}_{22}$ and some selected soil amendments on Fusarium wilt of eggplant (Solanum melongena L.). Applied Science Reports, 4(2):69-74.

Gurjar, R. B. S., Bansal, R. K. and Gupta, R. B. L. 2003. Effect of soil amendments on collar rot of chilli caused by Sclerotium rolfsii. Journal of Mycological Plant Pahtology, 33(3): 482.

Islam, M. 2005. Country news. Holiday publication limited, 8: 3-4.

Johnson, M., Reddy, P. N. and Reddy, D. R. 2008. Comparative efficacy of rhizosphere mycoflora, fungicides, insecticides and herbicides against groundnut stem rot caused by Sclerotium Rolfsii. Annals of Plant Protection Sciences, 16(2): 414-418.

Mian, I. H. 1995. Methods in plant pathology. IPSA-JICA Project Publication, 24:100.

Mirsha, B. K. and Bais, B. S. 1987. Studies on seedling blight and foot rot of barley caused by Sclerotium rolfsii. Indian Phytopathology, 40: 161-167.

Mohanty, B., Roy, J. K., Dasgupta, B. and Sen, C. 2000. Relative efficacy of promising fungicides and bio-control agent
Trichoderma in the management of foot rot of betel vine. Journal Plantation Crops, 28: 179-184.

Mukhopadhyay, 1994. Biological seeds treatment for control of soil borne pathogens FAO. Plant Protection Bulletin, 40: 21- 30.

Patil, M. R., Waghe, S. V., Wangikar, P. D. and Khune, N. N. 1986. Chemical control of wilt of betel vine. Pesticides, 20: 28-29.

Pranab, D. and Das, B. C. 2002. Management of collar rot of tomato by Trichoderma spp. and chemicals. Indian Phytopathology, 55(2): 235-237.

Rahman, M. L., Haque, M. S., Muqit, A., Alam, K. B. and Ali, S. 1994. Response of Phytophthora parasitica to different fungicides. Bangladesh Journal of Plant Pathology, 10: 1-2, 35-36.

Saralamrna, S. and Vithal, R. T. 2003. Integrated management of sclerotium root rot in groundnut. National seminar on stress management in oil seeds for attaining self reliance in vegetable oil Indian society of oil seeds research. Directorate of oil seeds research, Hyderabad, January 28 - 30. 20 $21 \mathrm{pp}$.

Sheoraj, S., Prajapati, R. K. and Srivastava, S. S. L. 2005. Efficacy of fungicides against Sclerotium Rolfsii causing collar rot in lentil, Farm Science Journal, 14(2): 6869.

Tiwari, R. K. and Ashok, S. 2004. Efficacy of fungicides on Rhizoctonia solani and Sclerotium rolfsii and their effect on Trichoderma harzianum and Rhizobium leguminosarum. Journal of Mycology and Plant Pathology, 34(2): 482-485.

Vanitha, S. and Suresh, M. 2002. Management of collar rot of brinjal (Sclerotium rolfsii) by non-chemical methods. South Indian Horticulture, 50(4-6): 602-606. 